from the Sun to the Earth are considered in Chapter 2. Several of the results obtained by the author some time ago have acquired new significance in view of present-day ideas on the extension of solar magnetic fields into interplanetary space. Chapter 3 contains an excellent account of the early theoretical work on the interaction of solar plasma with the geomagnetic field and the more recent studies of the shape of the steady-state hollow formed in the solar plasma by the Earth's magnetic field. This chapter is undoubtedly the best available summary of the detailed investigations in this branch of the subject. The main features of magnetic disturbances are described briefly in Chapter 4 . In the final chapter the terrestrial ring current is discussed in relation to the steady-state motion of a distribution of energetic charged particles trapped in a dipole field. This chapter summarizes one of the very few precise investigations of the geomagnetic effects of a symmetrical distribution of trapped radiation.

Much of the progress in the theory of magnetic storms has arisen from the formulation and solution of idealized problems in plasma dynamics. Prof. Chapman has been one of the chief exponents of this line of enquiry, and his present book provides an exemplary account of those basic concepts which form the foundations of the theory of geomagnetic storms. The book is a very valuable addition to the literature and is especially welcome at a time when speculation tends to outpace accepted theory.

D. M. WituIS

\section{DESTINY OF PROTEIN}

\section{Mammalian Protein Metabolism}

Edited by H. N. Munro and J. B. Allison. Vol. 1: pp. $\mathrm{xv}+566$. 132s. Vol. 2: pp. xiii +642. 150s. (New York: Academic Press, Inc.; London: Academic Press, Inc. (London), Ltd., 1964.)

NE of the earlier biochemical monographs in the pioneering series, edited by Plimmer and Hopkins, was the well-known book on protein metabolism written in 1912 by E. P. Cathcart. He defined his subject as "the processes in the animal organism which are concerned with the destiny of the protein, whether of the food or of the tissues". This definition is broad enough to cover the scope of the present book, but knowledge of the destiny of protein has advanced so much that it has now taken 27 authors and 2 author-editors to deal with the subject. The whole work is divided into three parts. The first part occupies all of Volume 1 and is concerned with the biochemical aspects of protein metabolism. It opens with an historical introduction by $\mathbf{H}$. N. Munro, beginning with the discovery of nitrogen and its biological consequences. This is followed by chapters on protein digestion and absorption in non-ruminants (C. Gitler) and in ruminants (A. T. Phillipson), and on free amino-acids and peptides in tissues (H. N. Christensen). H. A. Krebs deals fully with the metabolic fate of the amino-acids individually and with the ornithine cycle of urea formation. He also discusses the cause of the specific dynamic action of proteins. A. Korner deals with the mechanism of protein synthesis and A. Neuberger and F. F. Richards discuss protein turnover in the whole animal, including the problems arising in the interpretation of turnover data obtained with isotopes. This is followed by a chapter on plasma proteins (A. S. McFarlane) and there are two chapters on interrelationships between hormones and protein metabolism by J. H. Leathem and by $H$. N. Munro. Volume 1 ends with a chapter on nitrogen excretion by J. B. Allison and J. W. C. Bird.

Volume 2 contains parts 2 and 3 of the work, covering respectively nutritional aspects and pathological aspects of protein metabolism. Much of part 2 is concerned with protein requirements. $H$. N. Munro contributes an introduction and this is followed by a chapter by J. B. Allison on the nutritional value of dietary proteins and one by $\mathrm{A}$. $\mathrm{E}$.
Harper on amino-acid imbalances. D. M. Hegsted writes on protein requirements in general, and this is followed by chapters on protein metabolism and requirements in pregnancy and lactation (K. L. Blaxter), in the new-born (R. A. McCance and E. M. Widdowson), and in the elderly (D. M. Watkin). Part 3 opens with a general survey of pathological changes in protein metabolism (H. N. Munro), followed by a most useful chapter by L. E. Holt, jun., and S. E. Snyderman dealing with the many different congenital anomalies and acquired disturbances of amino-acid metabolism which have been described, particularly in recent years. More than $\mathbf{4 0}$ conditions are now known to be associated with an increased excretion of amino-acids in the urine. D. P. Cuthbertson contributes an article on physical injury and its effects on protein metabolism; then come chapters on protein metabolism in tumour growth (G. A. J. Goodlad), experimental protein. calorie deficiency (B. S. Platt, C. R. C. Heard and R. J. C. Stewart), clinical aspects of protein malnutrition ( $F$. Viteri, M. Béhar, G. Arroyave and N. S. Scrimshaw) and, finally, one on protein deficiency and infective disease (N. S. Scrimshaw).

This outline of the contents of the different chapters gives some indication of the wide scope of the work. The list of names of the authors is enough to indicate the high quality of the book, and the editors deserve congratulation on having persuaded so many distinguished workers to join them in this enterprise. The editors have done their work of planning and co-ordination admirably, and such overlapping between chapters as they have allowed, on infant nutrition for example, is helpful rather than otherwise. They have done much to unify the whole work by inserting cross-references where necessary. It seems surprising that they have not persuaded all the authors to use the internationally recommended coenzyme abbreviations NAD and NADP (rather than the old-fashioned DPN and TPN). Only a few misprints were noticed, but one of them ('possibly' in mistake for 'possible') unfortunately makes nonsense of the quotation at the beginning of the book. There are extensive lists of references at the ends of the chapters which greatly add to the usefulness of the book. Each of the two volumes is self-contained, with its own author index and subject index. The publication of this splendid monograph is of special importance at the present time when so much effort is being devoted to studying ways of improving the quality and quantity of food protein in the many countries where there is severe shortage. It is likely to remain the standard work on the subject for a long time to come. The book will interest a wide variety of people including workers in biochemistry, nutrition, agriculture and clinical science. Its publication must have created a problem for many librarians: not whether they should order a copy, but whether the library budget will allow them to order enough copies to satisfy the demand from scientists in so many different departments.

D. C. Harrison

\section{TROPICAL AND SUB-TROPICAL PLANT ECOLOGY}

\section{Die Vegetation der Erde in öko-physiologischer Betrachtung}

Von Prof. Heinrich Walter. Band 1: Die Tropischen und Subtropischen Zonen. Zweite, veränderte und erweiterte Auflage. Pp. 592 +9 tafeln. (Jena: Veb Gustav Fischer Verlag, 1964.) 68.10 D.M.

I HE first edition of this book was published in 1962 and reviewed in the April 6, 1963, issue of Nature. The second edition is enlarged by 54 pages; new matter consists of additional sections on competition and adaptation in Chapter 1, part of a new Chapter 3 on rain-forest of tropical mountains, a new section on the savannah 